\title{
A geometallurgical comparison between lump ore and pellets of manganese ore
}

\author{
G.L. Faria ${ }^{\text {a,* }}$, J.A.S. Tenório ${ }^{\text {b }}$, N. Jannotti Jr. ${ }^{\text {c }}$, F.G. da S. Araújo ${ }^{\mathrm{d}}$ \\ a Departamento de Engenharia Metalúrgica e de Materiais DEMET/UFOP, Campus Universitário Morro do Cruzeiro, Bauxita, Ouro Preto, MG, Brazil \\ b Universidade de São Paulo/USP, Brazil \\ c VALE Manganês, Brazil \\ d Rede Temática em Engenharia de Materiais/REDEMAT/UFOP, Brazil
}

\section{A R T I C L E I N F O}

\section{Article history:}

Received 6 January 2014

Received in revised form 1 December 2014

Accepted 4 March 2015

Available online 7 March 2015

\section{Keywords:}

Manganese lump ore

Characterization

Recycling

Pellets

Reduction

\begin{abstract}
A B S T R A C T
Manganese lump ores are still the main raw material used in the manufacture of manganese ferroalloys, but the processing of the ore to the beneficiation point generates fines. So an alternative to be studied is making pellets. This work compares the main geometallurgical characteristics of the lump ore from the Azul Mine and the pellets made from fines generated during beneficiation of this lump ore on a small scale. The characteristics assessed were: the chemical composition, mineralogical constitution, hot and cold particle disintegration, thermal decomposition and solid state reduction. It can be observed that the pellets contain a greater proportion of manganese oxides than the lump ore and they are also richer in Mn. In the pellets the hot and cold particle disintegration phenomena are minimal when compared with those found in lump ore. Lump ore can be efficiently reduced in the solid state, while most of the manganese minerals in the pellets have already been reduced to MnO. The conclusion is that manufacturing pellets in order to take advantage of the manganese ore fines is a path that must be studied further, since the pellets can be used as a viable source of manganese and act as agents that contribute to the increase in permeability of the charge. But possible reductions in the temperature of the granular zone during solid state reduction need to be considered.
\end{abstract}

(c) 2015 Elsevier B.V. All rights reserved.

\section{Introduction}

Manganese ferroalloys are mainly produced in electric reduction furnaces and are widely used as elements in steel alloys (Faria, 2011; Olsen et al., 2007; Tangstad et al., 2004).

Manganese lump ores are widely used as raw material for producing manganese ferroalloys. The mixtures of these ores, which come from various mines or even from different mining fronts in the same mine, are usually defined in ferroalloy plants exclusively according to their chemical and granulometric characteristics (Faria, 2011; Olsen et al., 2007; Tangstad et al., 2004; Faria et al., 2013a).

A frequently encountered problem in the mineral processing of limp ore from mines is the significant generation of fines that are rich in manganese, but whose granulometry is unsuitable for the reduction process in an electric furnace. In this context, this work presents a comparative study of the quality parameters (that are still little studied aspects) of the lump ore from the Azul Mine, which are solid state reduction, cold particle disintegration, granular crepitation and hot particle disintegration, and of manganese ore pellets made on a small scale from fines

\footnotetext{
* Corresponding author.

E-mail addresses: geraldolfaria@yahoo.com.br (G.L. Faria), jtenorio@usp.br (J.A.S. Tenório), nelson.jannotti@vale.com (N. Jannotti), fgabrielaraujo@uol.com.br (F.G.S. Araújo).
}

resulting from the processing of lump ore from Azul (Faria, 2011; Yoshikoshi et al., 1983).

The Azul manganese mine is the largest producer of manganese ore in Latin America, with annual production of 2.5 million tons. The ore produced is used mainly for producing ferroalloys and, to a lesser extent, in the chemical and battery industries. This mine is located in the mineral province of Carajás, in the Carajás National Forest, in the State of Pará. The ore extracted from this mine mainly comprises oxides like cryptomelane, in the biggest proportion, and others like magnetite and pyrolusite. Hydroxides, like n-sutite and gibbsite also occur (Faria, 2011; Faria et al., 2013a).

The focus of this research is on the metallurgical properties of the lump ore from Azul and the pellets produced from its fines in the solid state reduction zone of the electric reduction furnace. This is an important region in the alloy-making process. By comparing the chemical, mineral and metallurgical characteristics it is intended to evaluate the possibility of making manganese ore pellets as a possible way of taking advantage of the fines generated in the beneficiation process of lump ore.

In the solid state reduction zone of the electric furnace the solid raw materials undergo an increase in temperature as they flow down. The temperature of the charge in this zone varies between $500{ }^{\circ} \mathrm{C}$ and $1100{ }^{\circ} \mathrm{C}$, on average. In this region the water, present in the form of humidity, evaporates and the manganese oxides are reduced by the rising 
Table 1

A comparison of the chemical composition of lump ore from Azul and pellets.

\begin{tabular}{|c|c|c|c|c|c|c|c|c|}
\hline \multirow[t]{2}{*}{ Sample } & $\mathrm{Mn}$ & $\mathrm{Fe}$ & $\mathrm{SiO}_{2}$ & $\mathrm{P}$ & $\mathrm{Al}_{2} \mathrm{O}_{3}$ & $\mathrm{CaO}$ & $\mathrm{MgO}$ & $\mathrm{TiO}_{2}$ \\
\hline & $\%$ & $\%$ & $\%$ & $\%$ & $\%$ & $\%$ & $\%$ & $\%$ \\
\hline MG60 (overall) & 47.68 & 3.59 & 3.16 & 0.097 & 5.22 & 0.120 & 0.180 & 0.240 \\
\hline $\begin{array}{l}\text { MG60 }(-15.9 \mathrm{~mm}+ \\
\quad 9.5 \mathrm{~mm})\end{array}$ & 49.10 & 3.37 & 2.46 & 0.100 & 4.86 & 0.154 & 0.100 & 0.259 \\
\hline $\begin{array}{l}\text { Pellets }(-13 \mathrm{~mm}+ \\
\quad 11 \mathrm{~mm})\end{array}$ & 50.94 & 7.53 & 8.00 & 0.092 & 7.80 & 0.27 & 0.32 & 0.43 \\
\hline
\end{tabular}

flow of CO. In order for the process involved in this zone to be effective it is important that the permeability of the gas flow is high and homogenous throughout the charge (Faria, 2011; Berg and Olsen, 2000; Faria et al., 2012, 2013b).

According to Berg and Olsen (2000) and Wang and Sundman (1992) in addition to the physical integrity of the charge it is important that the reduction of the higher oxides is effective. According to the authors, the main reduction reactions in manganese oxides can be described in the following sequence: in the temperature band between $600{ }^{\circ} \mathrm{C}$ and $700{ }^{\circ} \mathrm{C}$ there is a significant reduction from $\mathrm{MnO}_{2}$ to $\mathrm{Mn}_{2} \mathrm{O}_{3}$, with a loss of mass of the order of $9.2 \%$. Between $900{ }^{\circ} \mathrm{C}$ and $1000{ }^{\circ} \mathrm{C}$ there is a significant reduction from $\mathrm{Mn}_{2} \mathrm{O}_{3}$ to $\mathrm{Mn}_{3} \mathrm{O}_{4}$, with a loss of mass of the order of $3.3 \%$. When it reaches temperatures in excess of $1200{ }^{\circ} \mathrm{C}$, which vary depending on the raw material and the type of alloy to be produced, the charge, with the exception of carbon, softens and melts (Faria, 2011; Faria et al., 2010, 2013b; Wang and Sundman, 1992; Zaki et al., 1997).

In this context, this work proposes a physical simulation methodology of the solid state reduction process under similar conditions to those found in an electric reduction furnace, in order to assess the physical integrity of the lump ore and pellets, as well as their reduction characteristics.

\section{Materials and methods}

A ton of lump ore from Azul was homogenized, quartered and representative samples weighing $100 \mathrm{~kg}$ were taken from both the overall sample and from the granulometric band containing particle sizes between $9.5 \mathrm{~mm}$ and $15.9 \mathrm{~mm}$. Both the overall sample and the sample from the granulometric band chosen were submitted to chemical, physical and mineralogical characterization procedures. A part of the sample, whose average particle size was between $9.5 \mathrm{~mm}$ and $15.9 \mathrm{~mm}$, was set aside for metallurgical tests.

A $100 \mathrm{~kg}$ batch of manganese ore pellets (74\% in weight, with an average diameter of between $11 \mathrm{~mm}$ and $13 \mathrm{~mm}$ ) made on a small scale from fines generated in processing the lump ore from Azul was also homogenized and quartered. Representative samples were sent for chemical, physical, mineralogical and metallurgical testing.

The $\mathrm{Mn}, \mathrm{Fe}, \mathrm{CaO}, \mathrm{MgO}, \mathrm{SiO}_{2}, \mathrm{Al}_{2} \mathrm{O}_{3}, \mathrm{TiO}_{2}$ and $\mathrm{P}$ concentrations were determined. The concentrations of $\mathrm{Mn}$ and $\mathrm{SiO}_{2}$ were determined by titration and the other components by ICP-OES (inductively coupled plasma optical emission spectrometry).

The main mineral constituents in the sample studied were quantitatively determined. The results were obtained by a combination of techniques involving optical microscopy, X-ray diffractometry, the total powder method, an electronic microprobe coupled to a scanning
Table 3

Microstructural constitution of pellets made from lump ore fines from Azul.

\begin{tabular}{lllll}
\hline Sample & \multicolumn{3}{l}{ Constituents (\% in weight) } \\
\cline { 2 - 5 } & $\begin{array}{l}\text { MnO } \\
\text { (Manganosite) }\end{array}$ & $\begin{array}{l}\mathrm{Mn}_{3} \mathrm{O}_{4} \\
\text { (Hausmannite) }\end{array}$ & $\begin{array}{l}\mathrm{Fe}_{3} \mathrm{O}_{4} \\
\text { (Magnetite) }\end{array}$ & Others \\
\hline Pellets & $64-60$ & $5-3$ & $12-9$ & $25-20$ \\
\hline
\end{tabular}

electron microscope, thermogravimetry and mass scales. The physical properties assessed were density (apparent and structural) and the porosity parameters.

Once the samples had been characterized, methodologies were proposed for the metallurgical characterization of the materials that are the focus of this work. Over and above the chemical, physical and mineralogical characteristics, the experimental methods allowed for a comparison of the thermal decomposition behaviors to air, solid state reduction and particle disintegration.

The first experimental methodology allowed for a comparison of the thermal decomposition and solid state reduction of the materials. The studies of thermal decomposition and the solid state reduction efficiency were undertaken by submitting samples to heating, from room temperature to as much as $1000^{\circ} \mathrm{C}$, at a constant rate of $25^{\circ} \mathrm{C} / \mathrm{min}$. The time it stayed at this temperature was $1 \mathrm{~h}$. The assays were carried out in a vertical resistance furnace, with a thermobalance. For the thermal decomposition tests the atmosphere used was fresh air. For the solid state reduction efficiency tests, however, an atmosphere comprising $5 \mathrm{NL} / \mathrm{min}$ of $100 \% \mathrm{~N}_{2}$ was used during heating, while different outputs of $99.5 \% \mathrm{CO}$ and $0.5 \% \mathrm{~N}_{2}(2 \mathrm{Nl} / \mathrm{min}, 5 \mathrm{Nl} / \mathrm{min}$ and $15 \mathrm{Nl} / \mathrm{min})$ were used during the isotherm test.

By the chemical analysis and X-ray diffractometry of the assay products, as well as the mass losses observed during heating, the temperatures at the beginning of decomposition of the less stable phases were determined, as were the fractions in the final sample structure of each product resulting from the decomposition and reduction. Each assay was carried out twice.

A quantitative index was proposed for assessing the mechanical behavior of the materials when cold; their resistance to impact and abrasion. This index was defined as the Cold Disintegration Index (CDI) (Faria, 2011). The ore sample from the granulometric band between $9.5 \mathrm{~mm}$ and $15.9 \mathrm{~mm}$ was dried and then tumbled (for $30 \mathrm{~min}$, in three 10-minute spells) in an ISO9246-1 and ISO9246-2 certified rotating tumbler. The percentages in mass of material produced below the $9.5 \mathrm{~mm}, 6.3 \mathrm{~mm}, 3.3 \mathrm{~mm}, 5 \mathrm{~mm}, 1.18 \mathrm{~mm}, 0.6 \mathrm{~mm}$ and $0.150 \mathrm{~mm}$ meshes provided the CDIs. The pellets were submitted to the same methodology, but the average size band of the pellets used was between $11 \mathrm{~mm}$ and $13 \mathrm{~mm}$.

The aim was to try and assess the mechanical behavior of the material as it flows down the metallurgical reactor, against a rising jet of gas that is rich in $\mathrm{CO}$, while undergoing heating. A parameter was proposed and defined as the Heating Disintegration Index (HDI) (Faria, 2011). The granulometric band chosen for measuring this index was also located between $9.5 \mathrm{~mm}$ and $15.9 \mathrm{~mm}$ for the lump ore from Azul and between $11 \mathrm{~mm}$ and $13 \mathrm{~mm}$ for the pellets. The granulometric bands used for the lump ore and pellets were selected because they were considered optimal bands for the operation of the electric furnace.

To determine the HDIs, two amounts of $500 \mathrm{~g}$ of material were individually placed in a retort that was $75 \mathrm{~mm}$ in diameter and heated in a

Table 2

Mineralogical constitution of the lump ore from Azul (MG60).

\begin{tabular}{|c|c|c|c|c|c|c|c|}
\hline \multirow[t]{2}{*}{ Sample } & \multicolumn{7}{|c|}{ Constituents (\% in weight) } \\
\hline & $\begin{array}{l}\mathrm{KMn}_{8} \mathrm{O}_{16} \\
\text { (Cryptomelane) }\end{array}$ & $\begin{array}{l}(\mathrm{Na}, \mathrm{Ca}, \mathrm{K})_{2} \mathrm{Mn}_{6} \mathrm{O}_{12} \cdot 3 \mathrm{a} 4,5\left(\mathrm{H}_{2} \mathrm{O}\right) \\
\text { (Todorokite) }\end{array}$ & $\begin{array}{l}\mathrm{Mn}(\mathrm{O}, \mathrm{OH})_{2} \\
\text { (N-Sutite) }\end{array}$ & $\begin{array}{l}\mathrm{Al}(\mathrm{OH})_{3} \\
\text { (Gibbsite) }\end{array}$ & $\begin{array}{l}\mathrm{MnO}_{2} \\
\text { (Pyrolusite) }\end{array}$ & $\begin{array}{l}\mathrm{Fe}_{3} \mathrm{O}_{4} \\
\text { (Magnetite) }\end{array}$ & Others \\
\hline MG60 (overall) & $33-23$ & $33-23$ & $16-10$ & $13-10$ & $4-2$ & $7-5$ & $8-7$ \\
\hline $\operatorname{MG} 60(-15.9 \mathrm{~mm}+9.5 \mathrm{~mm})$ & $35-25$ & $31-21$ & $16-10$ & $10-7$ & $5-3$ & $6-4$ & $8-7$ \\
\hline
\end{tabular}


Table 4

Bulk and structural densities and porosities of the lump ore from Azul (MG60) and of pellets.

\begin{tabular}{lccc}
\hline Samples & $\begin{array}{l}\text { MG60 } \\
\text { (overall) }\end{array}$ & $\begin{array}{l}\text { MG60 }(-15.9 \mathrm{~mm}+ \\
9.5 \mathrm{~mm})\end{array}$ & Pellets \\
\hline Bulk density $\left(\mathrm{g} / \mathrm{cm}^{3}\right)$ & 3.55 & 3.20 & 3.82 \\
Structural density $\left(\mathrm{g} / \mathrm{cm}^{3}\right)$ & 3.98 & 3.71 & 4.17 \\
Total porosity $(\%)$ & 10.9 & 13.8 & 8.2 \\
Total porosity $\left(\mathrm{cm}^{3} / \mathrm{kg}\right)$ & 30.6 & 43.1 & 21.5 \\
\hline
\end{tabular}

vertical resistance furnace (ISO-certified for Reduction Disintegration Index (RDI) and reducibility assays of iron ore), from room temperature to $1000^{\circ} \mathrm{C}$, at a constant rate of $25^{\circ} \mathrm{C} / \mathrm{min}$, in an atmosphere comprising $100 \% \mathrm{~N}_{2}$ in an ascending flow ( $5 \mathrm{Nl} / \mathrm{min}$ ). When it reached the residence time temperature the flow of $\mathrm{N}_{2}$ was interrupted and the reducing atmosphere in an ascending flow was established $(2 \mathrm{Nl} / \mathrm{min}, 5 \mathrm{Nl} / \mathrm{min}$ and $15 \mathrm{Nl} / \mathrm{min}$ of $99.5 \% \mathrm{CO}$ and $0.5 \% \mathrm{~N}_{2}$ ). The residence time in this temperature was $1 \mathrm{~h}$. At the end of the residence time the flow of reducing gas was interrupted and the sample was cooled inside the furnace under an ascending flow of $\mathrm{N}_{2}(5 \mathrm{Nl} / \mathrm{min})$.

After cooling, the samples underwent granulometric classification in the $9.5 \mathrm{~mm}, 6.3 \mathrm{~mm}, 3.35 \mathrm{~mm}, 1.18 \mathrm{~mm}, 0.6 \mathrm{~mm}$ and $0.150 \mathrm{~mm}$ meshes to obtain the particle disintegration indices during heating in a reducing atmosphere without tumbling. Once these indices had been obtained the samples were recomposed and tumbled in a rotary tumbler with a rotation frequency of $30 \pm 1 \mathrm{rpm}$. Tumbling was interrupted after $10 \mathrm{~min}, 20 \mathrm{~min}$ and $30 \mathrm{~min}$ of assaying to determine the disintegration indices.

The products of the hot crepitation and particle disintegration tests were characterized by reflected light optical microscopy and water pycnometry.

\section{Results and discussion}

Table 1 shows the chemical analyses overall and by particle band between $9.5 \mathrm{~mm}$ and $15.9 \mathrm{~mm}$ of the lump ore from Azul. The same table also compares the chemical composition of the pellets made on a small scale from the lump ore from Azul.

The lump ore from Azul (47.7\% in the overall sample) and the pellets (50.9\%) have a manganese content considered good for the process. The difference in manganese content reaches 3.2\%. The lump ore from Azul has a $\mathrm{Mn} / \mathrm{Fe}$ ratio of 13.3 , while that of the pellets is 6.8. The low $\mathrm{Mn} / \mathrm{Fe}$ ratio found in the pellets is the consequence of a significant concentration of $\mathrm{Fe}$, which is not desirable when making some types of alloy.

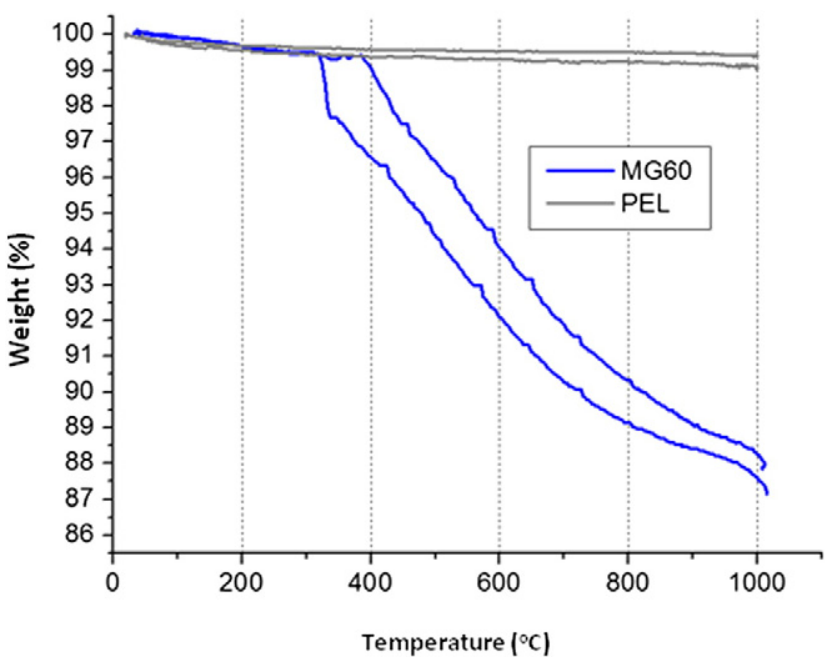

Fig. 1. Variation in mass during heating in air, up to $1000{ }^{\circ} \mathrm{C}$.

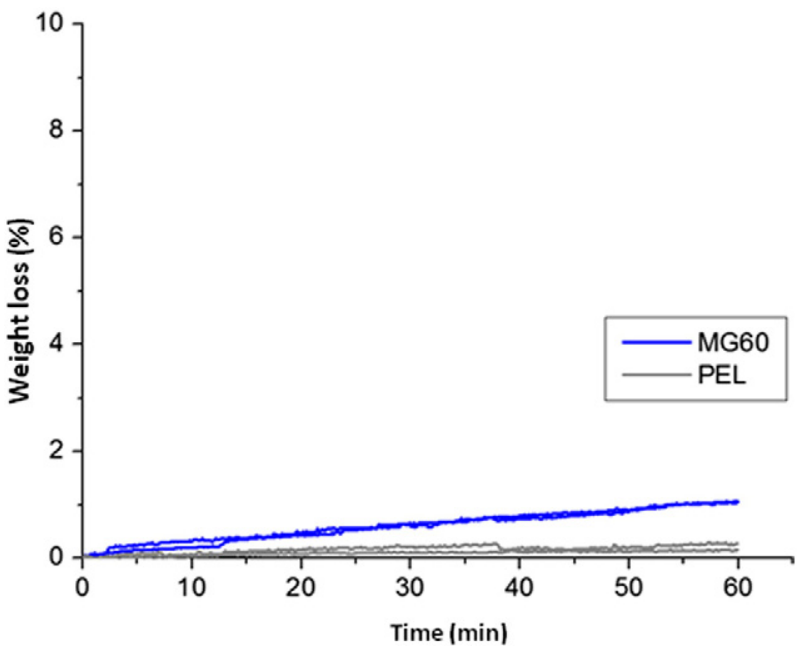

Fig. 2. Mass loss over time during isothermal treatment at $1000{ }^{\circ} \mathrm{C}$ in air.

The chemical characteristics of the lump ore allow for greater freedom in the selection and addition of ferriferous charges in the electric furnace. Because of its $\mathrm{SiO}_{2}$ (3.2\%) and $\mathrm{CaO}(0.12 \%)$ concentrations, its reduction without additives is likely to generate an acidic slag, with slightly limited fluidity and reactivity. The chemical characteristics of the pellets may be responsible for an intermediate metal/slag ratio, with the possible formation of an acidic slag that may be formed at lower points in the electric reduction furnace and have limited fluidity and reactivity.

Table 2 shows the mineralogical constitution of the lump ore from Azul and of the pellets. The main carriers of $\mathrm{Mn}$ in the mineralogical constitution of this lump ore are the oxides of cryptomelane $\left[\mathrm{KMn}_{8} \mathrm{O}_{16}\right]$ and pyrolusite $\left[\mathrm{MnO}_{2}\right]$, and the hydroxides of todorokite [( $\mathrm{Na}, \mathrm{Ca}$, $\left.\mathrm{K})_{2} \mathrm{Mn}_{6} \mathrm{O}_{12} \cdot 3 \mathrm{a} 4,5\left(\mathrm{H}_{2} \mathrm{O}\right)\right]$ and n-sutite $\left[\mathrm{Mn}(\mathrm{O}, \mathrm{OH})_{2}\right]$. The level of $\mathrm{Al}$ is justified by the presence of gibbsite $\left[\mathrm{Al}(\mathrm{OH})_{3}\right]$, and the Fe by the presence of magnetite $\left[\mathrm{Fe}_{3} \mathrm{O}_{4}\right]$. Because of this constitution the lump ore from Azul may be typologically classified as microporous, hydrated and oxidized.

The micro-structural constitution of the pellets is shown in Table 3. It can be seen that the main bearer structure of $\mathrm{Mn}$ is the oxide, $\mathrm{MnO}$, which has a crystalline structure corresponding to that of the mineral, manganosite (MnO). There is also a small amount of $\mathrm{Mn}_{3} \mathrm{O}_{4}$ as a bearer of Mn, which has a crystalline structure corresponding to the mineral,

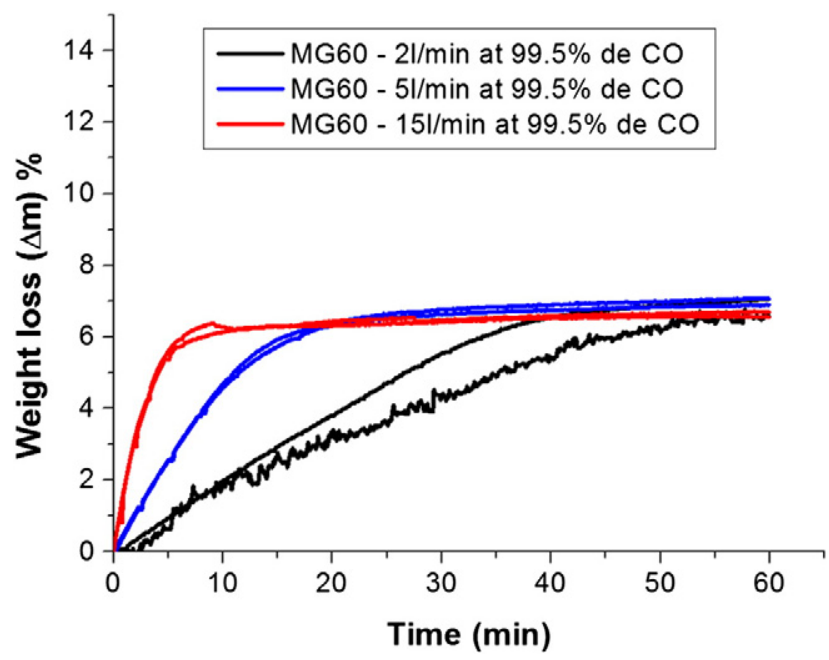

Fig. 3. Mass losses from samples of lump ore from Azul during solid state reduction at $1000{ }^{\circ} \mathrm{C}$ 


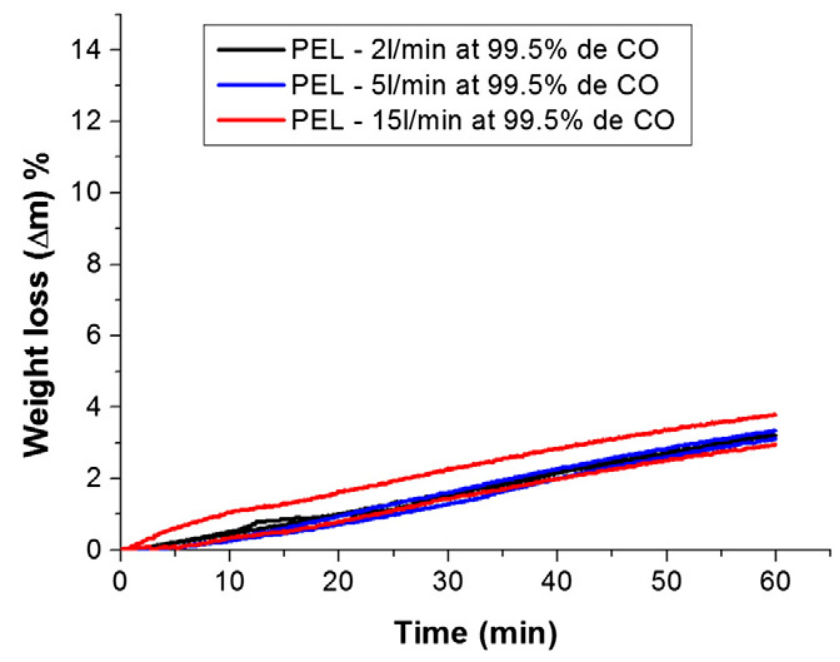

Fig. 4. Mass losses from pellet samples during solid state reduction at $1000{ }^{\circ} \mathrm{C}$.

hausmannite $\left(\mathrm{Mn}_{3} \mathrm{O}_{4}\right)$. The level of $\mathrm{Fe}$ is justified by the presence of magnetite in the pellet's structure. The chemical difference between the samples is a reflection of the fractions of each constituent in the characterized samples. This high concentration of $\mathrm{MnO}$ is due to the fact that the pellets had been sintered at temperatures in excess of $1100{ }^{\circ} \mathrm{C}$ with reactive carbon in their constitution, which partially reduces the higher oxides to $\mathrm{MnO}$. Because of this constitution, the pellets can be classified as macroporous, oxidized, and solid state reduced.

Table 4 gives a comparison between the bulk and structural densities and porosities of the samples studied. The pellets have the greatest structural and bulk densities, which are directly related to the fraction of the constituent, $\mathrm{MnO}$, which is associated with the sintering process to which they were submitted. The lump ore from Azul, because it has a high proportion of hydrated and porous mineral phases is more porous.

The methodology described for characterizing the behavior of the thermal decomposition of the materials being studied enabled the variation in mass of the samples - caused by temperature, during heating in air from room temperature to $1000{ }^{\circ} \mathrm{C}$ - to be determined. Fig. 1 shows a comparison between the mass loss profiles during heating and Fig. 2 shows them during $1 \mathrm{~h}$ of isothermal treatment at $1000^{\circ} \mathrm{C}$.

It can be seen that the variation in mass profiles during heating are completely different. When the lump ore from Azul is being heated to

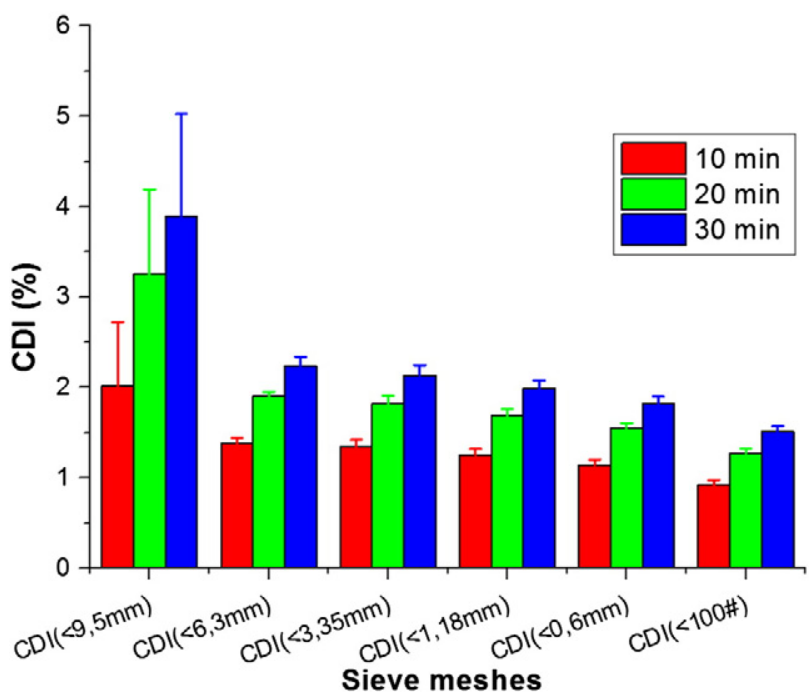

Fig. 5. Cold Particle Disintegration Indices (CDI) of the lump ore from Azul.

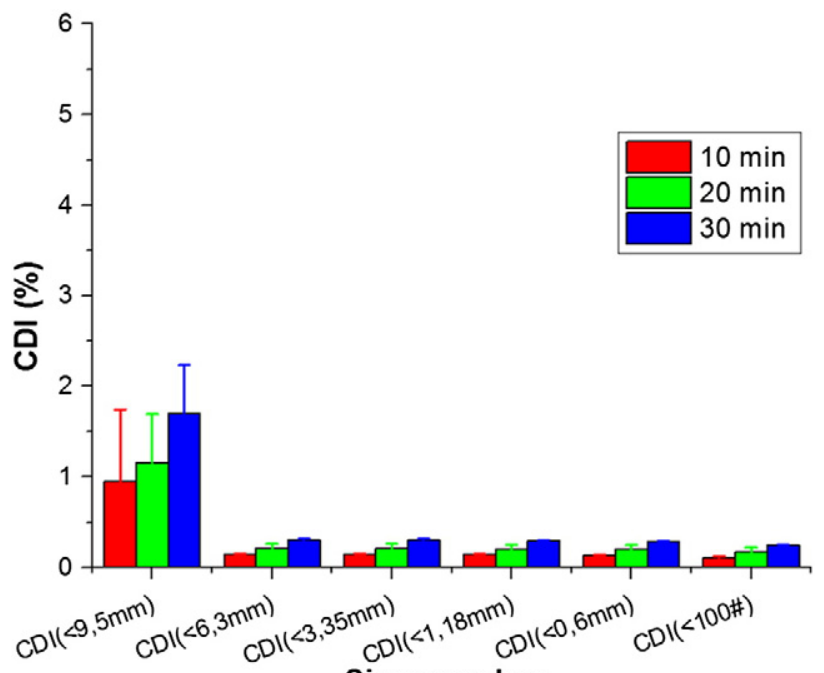

Sieve meshes

Fig. 6. Cold Particle Disintegration Indices (CDI) of the pellets.

$1000{ }^{\circ} \mathrm{C}$, there is an average mass loss of $11.9 \%$. This loss in mass is associated with the decomposition of the todorokite, n-sutite, and gibbsite, which are the hydrated minerals that are present, and the oxides of manganese, cryptomelane and pyrolusite.

When the pellets are being heated there was no appreciable variation in mass, but just a small reduction that occurs before $200{ }^{\circ} \mathrm{C}$. This can undoubtedly be attributed to the elimination of water from the humidity present in the sample holder. This behavior can be justified by the fact that the pellets had already been submitted to a sintering process at temperatures over $1100{ }^{\circ} \mathrm{C}$ when they were being made.

In seeking to assess the solid state reduction behavior of the samples studied they were heated up to $1000{ }^{\circ} \mathrm{C}$ and then submitted to different amounts of reducing gas for an hour (99.5\% CO and 0.5\% $\mathrm{N}_{2}$ ). Figs. 3 and 4 show the mass loss profiles as a function of the isothermal treatment time for the different flows studied for the lump ore from Azul and for the pellets, respectively.

It can be seen that the flow of reducing gas has a direct influence on the solid state reduction behavior of the lump ore from Azul. The greater the flow of gas, the greater the solid state reduction speed. It is also

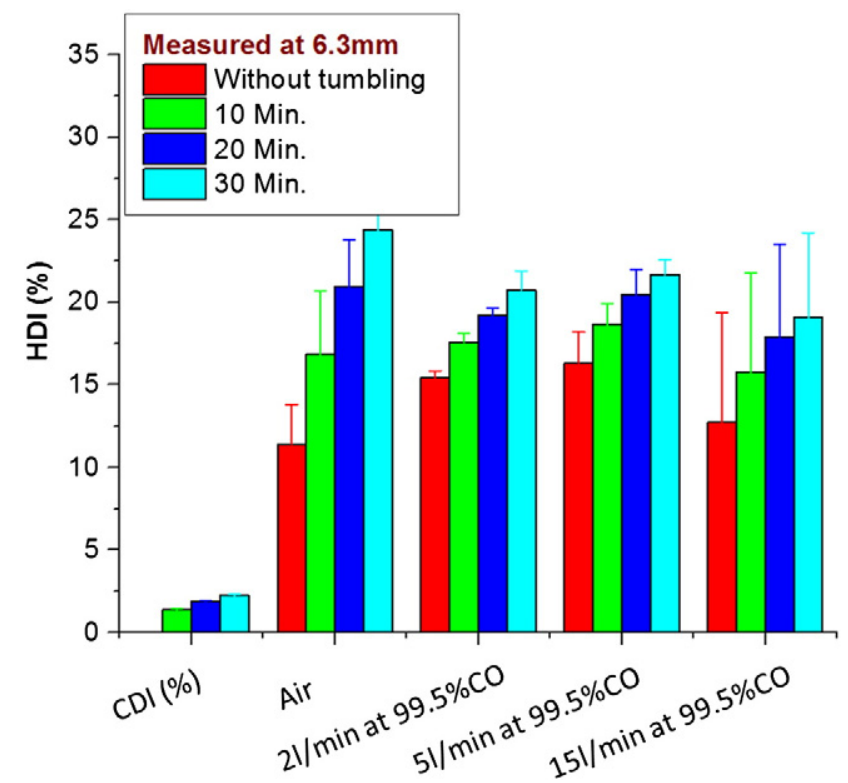

Fig. 7. Comparison between the CDIs and HDIs measured in a $6.3 \mathrm{~mm}$ mesh sieve for lump ore from Azul. 


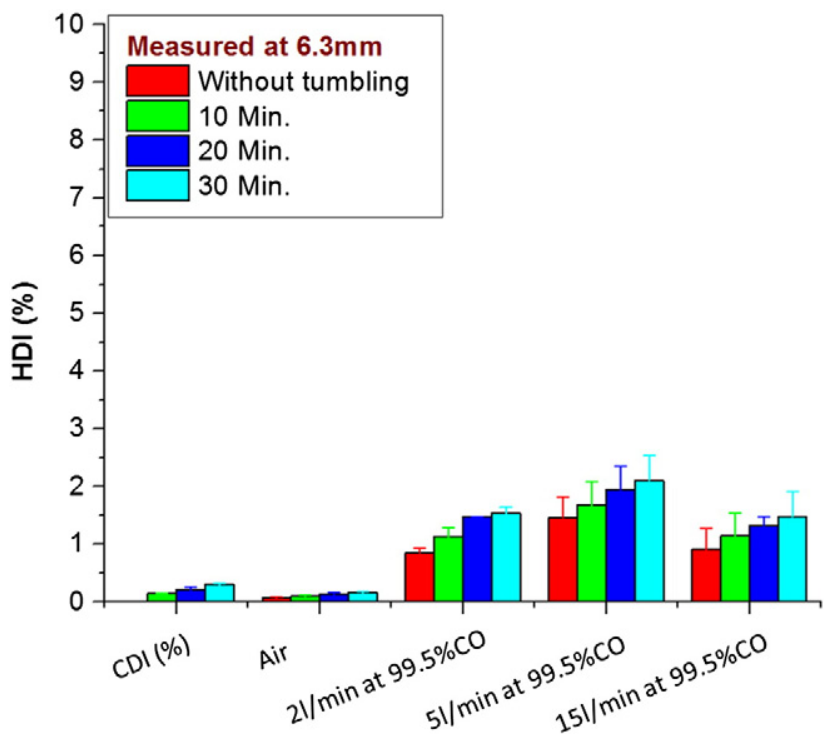

Fig. 8. Comparison between CDI's and HDIs measured in a $6.3 \mathrm{~mm}$ mesh sieve for pellets.

noted that for the three flows tested, the total mass losses were very similar, providing evidence that all the reactions were processed, but with different kinetics.

It can also be observed that the flow of reducing gas does not have a significant influence on the solid state reduction of the pellets studied, because they are already in an advanced state of pre-reduction. The small differences between the loss of mass profiles during solid state reduction may be associated with the different proportions of each phase in each sample.

As for characterization of the particle disintegration of the materials analyzed, the first assay was proposed with the objective of assessing cold particle disintegration by way of the CDI, as suggested by Faria (2011). Figs. 5 and 6 give the fines generation profiles at room temperature of the lump ore from Azul and the pellets, respectively.

For the tumbling conditions studied it can be seen that both the lump ore from Azul and the pellets generate very few fines, although the pellets behave better in this respect. After 30 minutes of tumbling $2.2 \%$ of the lump ore material from Azul passed through the $6.3 \mathrm{~mm}$ mesh, while with pellets it was only $0.3 \%$.

Figs. 7 and 8 show a comparison between the CD and Hot Particle Disintegration (HDI) indices, also proposed by Faria (2011), for the lump ore from Azul and for the pellets, respectively. It can be seen that the pellets are more resistant to particle disintegration than the lump ore from Azul under all assay conditions.

It is supposed that the removal of oxygen resulting from the solid state reduction of the samples significantly increases the porosity of the same, thus justifying the increase in the generation of fines. In pellets this structural damage is presumably less severe, because they are already in an advanced state of pre-reduction after being made.

\section{Conclusions}

Lump ore from Azul has a 47.7\% level of Mn and an Mn/Fe ratio of 13.3. Pellets have a higher concentration of Mn (50,9\%), but a lower $\mathrm{Mn} / \mathrm{Fe}$ ratio (6.8).

Lump ore from Azul is rich in hydrated manganese minerals (todorokite and $\mathrm{n}$-sutite). There is a significant occurrence of manganese oxides (cryptomelane and pyrolusite) and iron (magnetite). Among others minerals, this ore has a significant amount of gibbsite. Lump ore from Azul may be typologically classified as hydrated, oxidized and microporous. The pellets studied constituted mainly of oxides. The main oxides are $\mathrm{MnO}$ and $\mathrm{Fe}_{3} \mathrm{O}_{4}$. They may be classified as oxidized, prereduced and macroporous.

Structural water is eliminated from the lump ore from Azul at between $350{ }^{\circ} \mathrm{C}$ and $500{ }^{\circ} \mathrm{C}$. The oxides with a higher valence start disintegrating when the temperature reaches $600^{\circ} \mathrm{C}$. There is no significant loss of mass in pellets, indicating that all the phases present are thermodynamically stable under study conditions.

During solid state reduction, the loss of mass of the lump ore from Azul is greater than for pellets. The lump ore proves to be very sensitive to any variation in the flow of reducing gas, while the pellets are not. As the pre-reduction reactions of the manganese oxides are exothermic they will not contribute towards maintaining the thermal profile of the metallurgical reactor if they are used as the only source of $\mathrm{Mn}$ in the process.

The pellets and the ore studied resist cold particle disintegration well and generate $0.3 \%$ and $2.2 \%$ of fines that pass through a $6.3 \mathrm{~mm}$ mesh sieve after $30 \mathrm{~min}$ of tumbling, respectively.

Pellets undergo less particle disintegration during pre-reduction than lump ore from Azul. While on average the particle product generates between $20 \%$ and $25 \%$ of fines that pass through a $6.3 \mathrm{~mm}$ mesh, the pellets generate just $2 \%$.

Manufacturing pellets to take advantage of manganese ore fines is a process that should be studied, because pellets can be used as a feasible source of manganese and act as agents that contribute to the increase in permeability of the charge. Possible reductions in the temperature of the particle zone during pre-reduction should be considered.

\section{Acknowledgments}

The authors thank CAPES (Coordenação de Aperfeiçoamento de Pessoal de Nível Superior) for its financial support and VALE Manganês for kindly providing the samples.

\section{References}

Berg, K.L., Olsen, S.E., 2000. Kinetics of manganese ore reduction by carbon monoxide. Metall. Mater. Trans. B 31B, 477-490.

Faria, G.L., 2011. Estudo Geometalúrgico de Granulados e Pelota de Minério de Manganês. (Tese de Doutorado), Universidade Federal de Ouro Preto - REDEMAT, Ouro Preto, Brasil (302 pp., www.redemat.ufop.br).

Faria, G.L., Vianna, N.C.S., Jannoti, N., Vieira, C.B., Araujo, F.G.S., 2010. Decrepitation of Brazilian manganese lump ores. The Twelfth International Ferroalloys Congress INFACON XII (Helsink).

Faria, G.L., Jannotti, N., Araújo, F.G. da S., 2012. Decrepitation behavior of manganese lump ores. Int. J. Miner. Process. 150-155.

Faria, G.L., Tenório, J.A.S., Jannotti, N., Araújo, F.G.S., 2013a. Disintegration on heating of a Brazilian manganese lump ore. Int. J. Miner. Process. 8 (Print, p. MINPRO-02539-137).

Faria, G.L., Reis, E.L., Jannoti Jr., N., Araujo, F.G.S., 2013b. Chemical, physical and typological characterization of main Brazilian manganese lump ores. Lat. Am. Appl. Res. 43, 17-22.

Olsen, S.E., Tangstad, M., Lindstad, T., 2007. Production of Ferromanganese Alloys in the Submerged Arc Furnace (Trondheim, Norway, 247 pp.).

Tangstad, M., Calvert, P., Brun, H., Lindseth, A.G., 2004. Use of Comilog ore in ferromanganese production. INFACON 10, Cape Town, South Africa, pp. 213-222.

Wang, M., Sundman, B., 1992. Thermodynamic assessment of the Mn-O system. Metall. Trans. B 23B, 821-831

Yoshikoshi, H., Takeuchi, O., Miyashita, T., Kuwana, T., Kishikawa, K., 1983. Development of composite cold pellet for silico-manganese production. 105th ISIJ Meeting (Tokyo).

Zaki, M.I., Hasan, M.A., Pasupulety, L. e, Kumari, K., 1997. Thermochemistry of manganese oxides in reactive gas atmospheres: probing redox composition in the decomposition Course $\mathrm{MnO}_{2} \rightarrow \mathrm{MnO}$. Thermochim. Acta 303, 171-181. 